\title{
Fabrication of High Surface Area Microporous ZnO from ZnO/Carbon Sacrificial Composite Monolith Template
}

\author{
Kunal Mondal ${ }^{1,2, *,+}$ (D) Monsur Islam ${ }^{3,+}+\mathbb{D}$, Srujan Singh ${ }^{1}$ and Ashutosh Sharma ${ }^{1, *}$ \\ 1 Department of Chemical Engineering, Indian Institute of Technology, Kanpur 208016, Uttar Pradesh, India; \\ srujansingh91@gmail.com \\ 2 Materials Science and Engineering Department, Energy and Environment Science and Technology Directorate, \\ Idaho National Laboratory, Idaho Falls, ID 83415, USA \\ 3 Institute of Microstructure Technology, Karlsruhe Institute of Technology, Hermann-von-Helmholtz-Platz 1, \\ 76344 Eggenstein-Leopoldshafen, Germany; monsur.islam@kit.edu \\ * Correspondence: kunal.mondal@inl.gov (K.M.); ashutos@iitk.ac.in (A.S.) \\ + These authors contributed equally to this work.
}

Citation: Mondal, K.; Islam, M.; Singh, S.; Sharma, A. Fabrication of High Surface Area Microporous ZnO from $\mathrm{ZnO} /$ Carbon Sacrificial Composite Monolith Template. Micromachines 2022, 13, 335. https:// doi.org/10.3390/mi13020335

Academic Editor: Nam-Trung Nguyen

Received: 30 January 2022

Accepted: 18 February 2022

Published: 20 February 2022

Publisher's Note: MDPI stays neutral with regard to jurisdictional claims in published maps and institutional affiliations.

Copyright: (C) 2022 by the authors. Licensee MDPI, Basel, Switzerland. This article is an open access article distributed under the terms and conditions of the Creative Commons Attribution (CC BY) license (https:// creativecommons.org/licenses/by/ $4.0 /)$.

\begin{abstract}
Fabrication of porous materials from the standard sacrificial template method allows metal oxide nanostructures to be produced and have several applications in energy, filtration and constructing sensing devices. However, the low surface area of these nanostructures is a significant drawback for most applications. Here, we report the synthesis of $\mathrm{ZnO} /$ carbon composite monoliths in which carbon is used as a sacrificial template to produce zinc oxide $(\mathrm{ZnO})$ porous nanostructures with a high specific surface area. The synthesized porous oxides of $\mathrm{ZnO}$ with a specific surface area of $78 \mathrm{~m}^{2} / \mathrm{g}$ are at least one order of magnitude higher than that of the $\mathrm{ZnO}$ nanotubes reported in the literature. The crucial point to achieving this remarkable result was the usage of a novel $\mathrm{ZnO} / \mathrm{carbon}$ template where the carbon template was removed by simple heating in the air. As a high surface area porous nanostructured $\mathrm{ZnO}$, these synthesized materials can be useful in various applications including catalysis, photocatalysis, separation, sensing, solar energy harvest and Zn-ion battery and as supercapacitors for energy storage.
\end{abstract}

Keywords: $\mathrm{ZnO}$; porous metal oxides; bet surface area; sacrificial template

\section{Introduction}

The development of nanostructures of oxide materials with a high surface area to volume ratio with enough stability is vital for many applications needing improved surface chemistry [1-14]. Porous nanomaterials have gained significant interest and are being studied extensively in this respect $[15,16]$. The unique microstructures of those porous materials have engrossed considerable attention as a functional material owing to their variety and better performance during applications in the area of catalysis [17], photocatalysis [18], separation [19], adsorption [20], energy storage and conversion [21], and sensing to physicochemical devices [22-24] in recent years. These materials are usually characterized for their porosity at macro-, meso-, and microscale, uniformity of pores, hierarchy and interconnection between each level of porosity, large accessible high surface areas, low density and excellent accommodation capability of other nanomaterials into the pore volumes, which enables the easy transport of ion/electron/reactant and the diffusion of mass, exposing boundless significance in applications requiring high accessible surface for reactions such as the energy density, rate capacity and cycling life in energy storage and modulation of electronic activities for sensing $[25,26]$. Additionally, porous materials can improve the structural stability of the electrode materials for energy storage and sensor devices for their increasing cyclic life, owing to the large porous space and the interconnection of pores at various micro and nanoscopic length scales, which can accommodate not 
only the volume change [27] but also absorption and dispersion of chemical species [28,29] during a chemical reaction.

For the synthesis of porous nanostructured materials, there are several approaches, including soft and hard templating processes, that have been reported [30,31]. Additionally, electrochemical anodization [27], directed assembly [32], and a self-formation method based on a spontaneous phenomenon, using the chemistry of organic metal alkoxides and alkyl metals, was also strongly considered and effectively applied to the fabrication of a range of metal oxides, and composites of them, aluminophosphates, and silicoaluminate, with hierarchically porous architecture [33,34]. These methods can produce porous materials of various shapes and sizes with controlled pore morphologies.

Among these reported methods, the sacrificial templating process has shown utmost promise to synthesize porous nanomaterials [35,36]. Instances include the use of anodic alumina and polycarbonate templates for the synthesis of various porous metal nanostructures [37]. Some of these approaches use quite expensive sacrificial nano-templates and the removal of these templates is often challenging and overwhelming. Recently, silica nanostructures were used as templates to produce various carbon, metal oxide and metal porous nanostructures [38,39]. Carbon is another low-cost, easily available sacrificial template particularly for the fabrication of various porous nanostructures due to its favorable crystallography, and encouraging sphere/tuber/wire morphology [40]. However, the removal of carbon templates can be challenging. Interestingly, it can be easy to remove carbon templates under high-temperature heat treatment. Such a sacrificial carbon templating method can offer a distinct advantage for the synthesis of various porous/hollow nanostructures in a single step to synthesize various metal/metal oxide nano/microstructures for diverse applications. A thorough understanding of the mechanism of nucleation of nanostructures and removal of template and formation of pores is essential and much needed to control the nature of the resultant porous materials.

Here, using carbon as a sacrificial template, we carried out detailed control experiments to fabricate porous $\mathrm{ZnO}$ nanostructures and gain an understanding of the critical parameters for nanopore formation. Using these methods and understanding, we showed that it is possible to synthesize high BET surface area microporous $\mathrm{ZnO}$ nanostructures from $\mathrm{ZnO} /$ carbon composite monoliths. Synthesized high surface area porous zinc oxides with a specific surface area of $\sim 78.1 \mathrm{~m}^{2} / \mathrm{g}$ that are one order of magnitude greater than that of $\mathrm{ZnO}$ nanotubes are reported in the literature. These porous metal oxides were prepared using a novel $\mathrm{ZnO} /$ carbon composite architecture where the carbon was used as a template and removed by heating at high temperature in presence of air. We also carried out X-ray Diffraction (XRD), Field Emission Scanning Electron Microscope (FE-SEM) and Transmission Electron Microscope (TEM) studies to investigate the crystallinity, nanomorphology of the $\mathrm{ZnO}$ that is critical for applications including catalysis, photocatalysis, separation, sensing, solar energy harvest and Zn-ion battery and as a supercapacitor for energy storage.

\section{Experimental Section}

A simple sol-gel technique was used to prepare the precursor monolith. A total of $734 \mathrm{mg}$ of resorcinol (R, Sigma-Aldrich, St. Louis, MO, USA) and zinc chloride $\left(\mathrm{ZnCl}_{2}\right)$ was added to $4 \mathrm{~mL}$ acetone (Fischer Scientific, Waltham, MA, USA). A total of $1.5 \mathrm{~mL}$ of formaldehyde $(\mathrm{F})$ was added to this mixture and stirred over a hot plate to ensure proper mixture, which was essential to initiate the sol-gel reaction. The mixture was sealed and kept at room temperature for $12 \mathrm{~h}$ to complete the gelation process. The gel was further kept at $60^{\circ} \mathrm{C}$ for $12 \mathrm{~h}$ in an oven to obtain a dry precursor monolith. The resulting monolith appeared dark red.

The $\mathrm{ZnCl}_{2} / \mathrm{RF}$ monolith was carbonized in a horizontal tube furnace. A typical carbonization recipe was used, as mentioned several times for the fabrication of carbon microelectromechanical (C-MEMS) devices [41-45]. Briefly, the furnace temperature was raised to $900{ }^{\circ} \mathrm{C}$ from room temperature with a heating rate of $5^{\circ} \mathrm{C} / \mathrm{min}$, followed by a dwell at $900{ }^{\circ} \mathrm{C}$ for $2 \mathrm{~h}$. An ambient cooling was implemented after the dwell at $900^{\circ} \mathrm{C}$. 
A constant nitrogen gas flow was maintained at a flow rate of $0.15 \mathrm{~L} / \mathrm{min}$ throughout the entire process. These carbonization steps were followed to ensure mechanically stable and completely carbonized monoliths, as observed in the previous study [46]. An RF monolith was also prepared and carbonized for comparison using similar procedure. Upon carbonization, the $\mathrm{ZnCl}_{2} / \mathrm{RF}$ monolith-derived material was calcinated at $600{ }^{\circ} \mathrm{C}$ for $1 \mathrm{~h}$ using a heating rate of $5^{\circ} \mathrm{C} / \mathrm{min}$ to remove the carbon counterpart of the monolith and obtain porous $\mathrm{ZnO}$ nanoparticles.

The surface morphology of the prepared samples was characterized by field emission scanning electron microscopy (FESEM, Quanta 200, Zeiss, Oberkochen, Germany). The composition of the prepared sample was investigated using X-ray diffraction (XRD) using an X'Pert Pro (PAN analytical, Almelo, The Netherlands) X-ray system equipped with $\mathrm{Cu} \mathrm{K}_{\alpha}$ radiation. We used transmission electron microscopy (TEM, Tecnai $\mathrm{G}^{2}$, Hillsboro, OR, USA) for investigation of structural insights of the synthesized material. The porosity of the carbonized and oxidized materials was characterized by performing nitrogen gas adsorption-desorption experiments at $77 \mathrm{~K}$ using an ASC-1 setup (Quantachrome Instruments, Boynton Beach, FL, USA). The surface area was calculated based on the gas adsorption-desorption experiments using the Brunauer, Emmett and Teller (BET) model.

\section{Results}

Drying the precursor monolith in a sealed container allowed slow evaporation of the solvent molecules. The addition of $\mathrm{ZnCl}_{2}$ was apparent due to the physical appearances of the monoliths. The RF monolith appeared red, whereas the $\mathrm{ZnCl}_{2} / \mathrm{RF}$ monolith had a dark brownish-red color. The appearance change could be attributed to the formation of strong coordination bonds between the $\mathrm{Zn}^{2+}$ ions and the phenolic network of $\mathrm{RF}$.

A black monolith was obtained upon carbonization of the $\mathrm{ZnCl}_{2} / \mathrm{RF}$ monolith (Figure 1a), which was transformed into green nanoparticles upon calcination (Figure 1b). We performed Energy-dispersive X-ray spectroscopy (EDX) analysis of the $\mathrm{ZnO} /$ Carbon monolith and $\mathrm{ZnO}$ obtained after the burning of carbon from the $\mathrm{ZnO} /$ Carbon monolith and shown in Figure 1c,d. This analysis was needed to confirm the elemental composition of the monoliths and to confirm if there is any residual carbon in the $\mathrm{ZnO}$ after the calcination. It was found that there was no significant carbon present in the obtained $\mathrm{ZnO}$ powder.

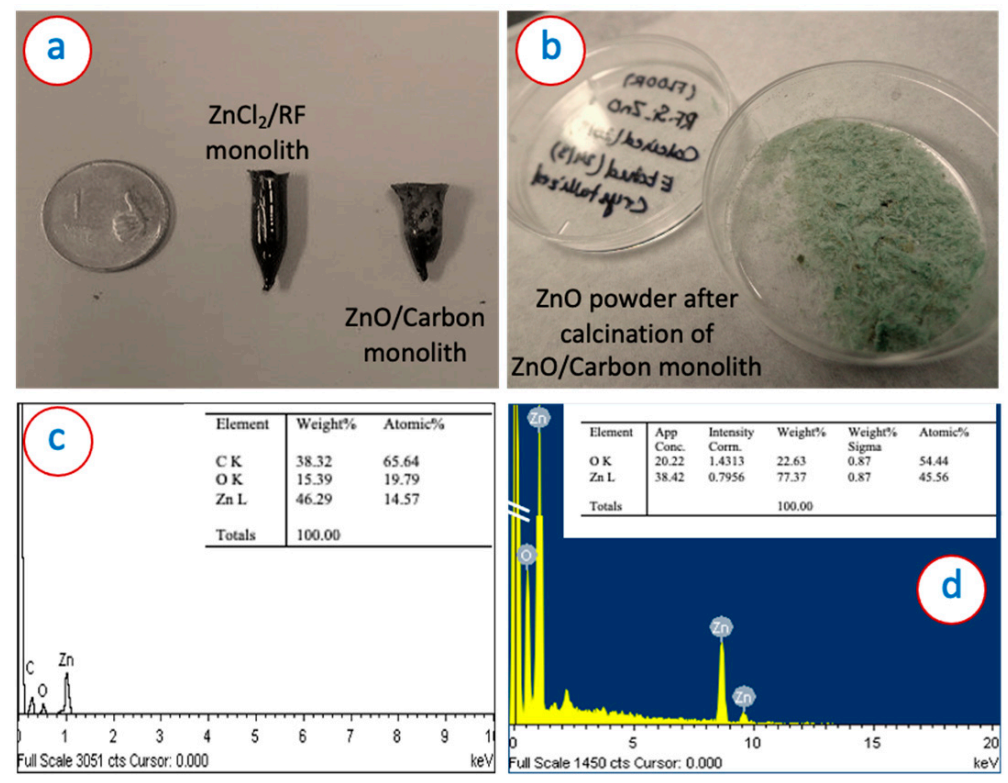

Figure 1. Digital image of (a) $\mathrm{ZnCl}_{2} / \mathrm{RF}$ and $\mathrm{ZnO} / \mathrm{Carbon}$ monolith, and (b) $\mathrm{ZnO}$ powder obtained from the calcination of $\mathrm{ZnO} /$ carbon monolith. EDS spectra and corresponding atomic wt.\% of (c) $\mathrm{ZnO} /$ carbon monolith, and (d) $\mathrm{ZnO}$ powder obtained from the calcination of $\mathrm{ZnO} /$ carbon monolith. 
XRD diffractograms of the materials are presented in Figure 2. The carbonized sample obtained from the RF monolith featured broad peaks around $2 \theta=26^{\circ}$ and $2 \theta=44^{\circ}$, which correspond to the reflections of (002) and (101) planes of carbon $[47,48]$. These broad peaks are characteristics of the turbostratic microstructure of carbon material, which agrees with previous publications dealing with RF-derived carbon materials [49,50]. In the XRD diffractogram of the carbonized $\mathrm{ZnCl}_{2} / \mathrm{RF}$ monolith, along with the strong reflection of (002) plane of carbon at $2 \theta=26^{\circ}$, distinctive peaks of $\mathrm{ZnO}$ appeared at $2 \theta=31.6^{\circ}, 34.3^{\circ}$, $36.1^{\circ}, 47.5^{\circ}$ and $56.5^{\circ}$, which correspond to (100), (002), (101), (102) and (110) crystal planes of $\mathrm{ZnO}$ and matched with the International Centre for Diffraction Data (ICDD) card number 36-1451. Several peaks of metallic Zn were also present in the diffractogram. The peaks for carbon and metallic Zinc disappeared in the XRD pattern of the calcinated sample; only peaks for $\mathrm{ZnO}$ were present in the diffractogram.

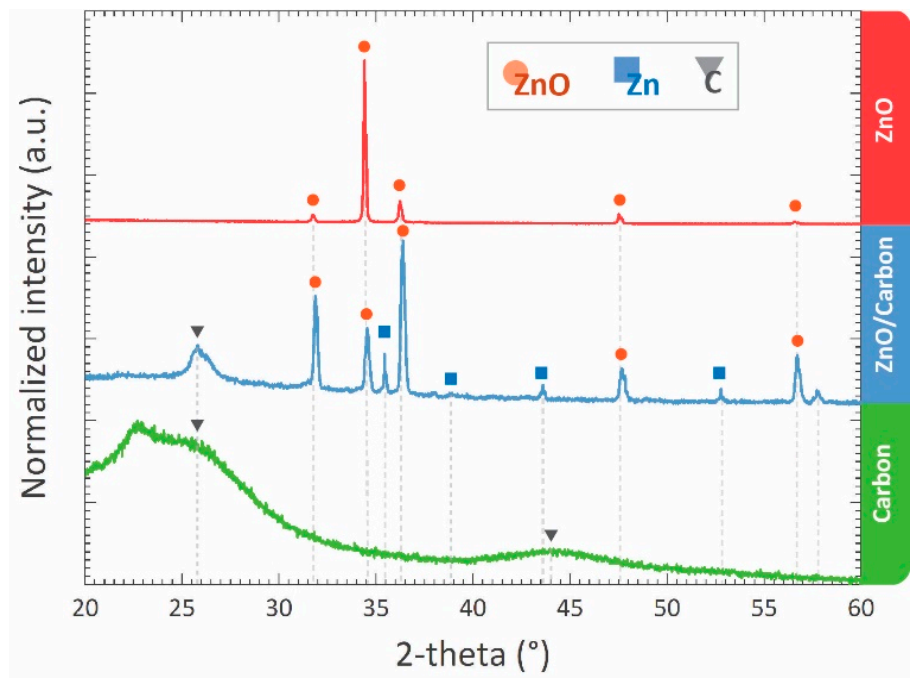

Figure 2. XRD diffractogram of carbonized $\mathrm{RF}$ gel, carbonized $\mathrm{ZnCl}_{2} / \mathrm{RF}$ monolith, and the sample obtained after the oxidation of $\mathrm{ZnCl}_{2} / \mathrm{RF}$-derived carbon monolith.

The Raman spectra shown in Figure 3 were captured at room temperature. Raman signals are subtle to the crystal structures and the defects associated with $\mathrm{ZnO}$. A major sharp peak was detected at $447 \mathrm{~cm}^{-1}$, which is characteristic of hexagonal wurtzite $\mathrm{ZnO}$. This peak corresponds to the Raman active optical phonon mode E2 (high) [51]. Other small peaks were observed at $334.6 \mathrm{~cm}^{-1}$ and $584.7 \mathrm{~cm}^{-1}$. The broad peak at $1153 \mathrm{~cm}^{-1}$ is due to multiple phonon scattering, and the peak at $584.7 \mathrm{~cm}^{-1}$ is observed due to structural defects such as oxygen deficiency [52]. The intensity of the peak at $100 \mathrm{~cm}^{-1}$ as compared to other peaks is high and corresponds to the Raman active optical phonon mode E2 (low), which indicates high crystal quality, and this result is consistent with the XRD [53].

Figure 4 presents SEM images of the samples prepared here. The RF gel-derived carbon seemed to feature a non-porous morphology, as no visible pores were observed under SEM (Figure 4a). Rather, the microstructure resembled a paste-like morphology, as depicted in Figure $4 \mathrm{~b}$. The $\mathrm{ZnO} /$ carbon sample featured crystallites with various sizes within the carbon matrix, as shown in Figure $4 \mathrm{c}$,d. In contrast to the carbonized samples, the $\mathrm{ZnO}$ material obtained after oxidization of $\mathrm{ZnCl}_{2} / \mathrm{RF}$-derived carbon monolith featured porous morphology with interconnected $\mathrm{ZnO}$ crystallites (Figure 4e). High magnification FESEM revealed that the $\mathrm{ZnO}$ crystallites featured a nanorod-like morphology with a diameter ranging from $500 \mathrm{~nm}$ to $1 \mu \mathrm{m}$. The $\mathrm{ZnO}$ material itself featured several tiny pores. The examples of such pores are indicated by the red circles in Figure 5a, where a TEM image of the porous $\mathrm{ZnO}$ is presented. The FFT of the TEM image further confirmed the formation of $\mathrm{ZnO}$ during the oxidation step. 


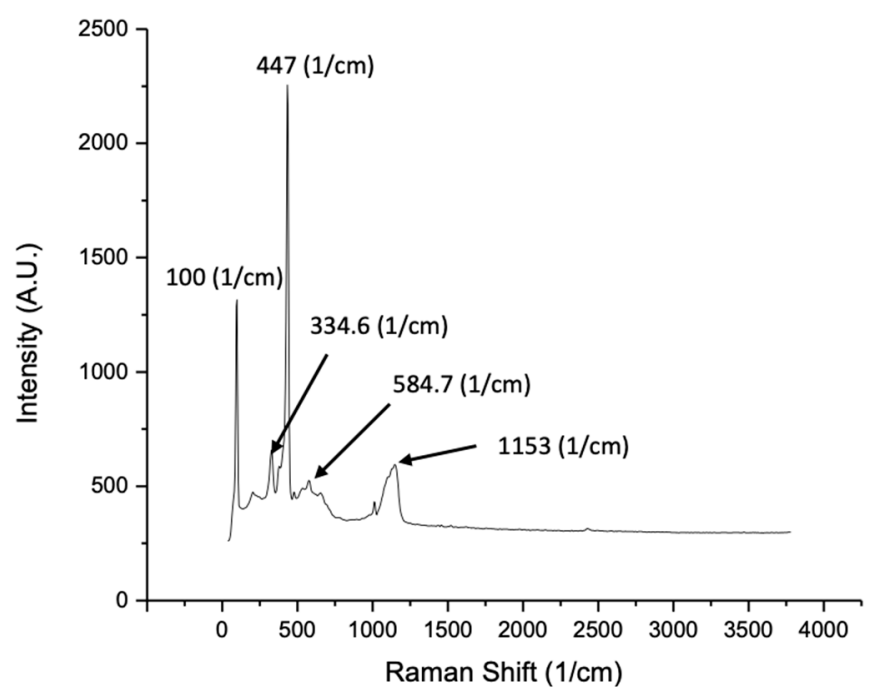

Figure 3. Raman analysis of $\mathrm{ZnO}$ powder obtained after calcination of $\mathrm{ZnO} /$ carbon monolith.
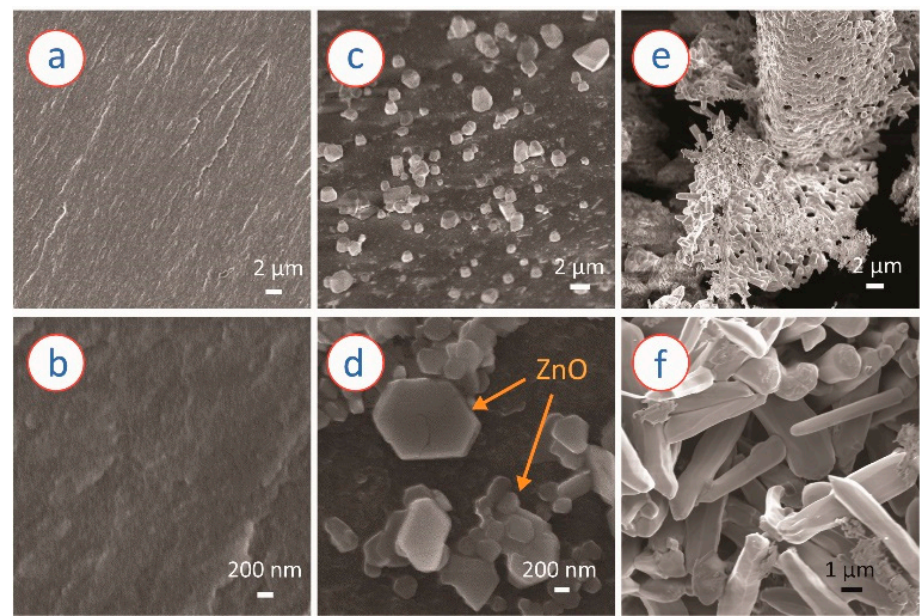

Figure 4. SEM image of (a,b) RF-derived carbon monolith, (c,d) $\mathrm{ZnCl}_{2} / \mathrm{RF}$-derived $\mathrm{ZnO} /$ carbon monolith, and (e,f) $\mathrm{ZnO}$ nanostructures obtained from the oxidation of $\mathrm{ZnO} /$ carbon monolith.
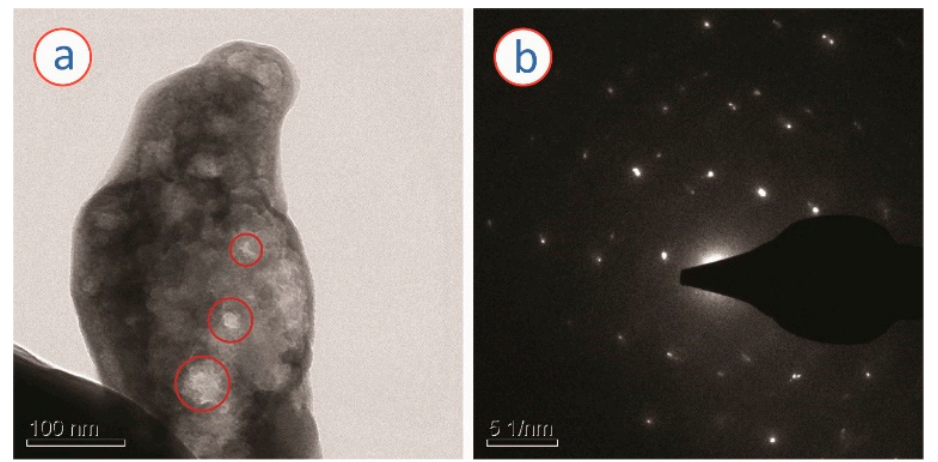

Figure 5. (a) TEM and (b) SAED of the $\mathrm{ZnO}$ nanostructures obtained from the oxidation of $\mathrm{ZnO} /$ carbon monolith. The red circles in (a) indicate the presence of pores within the material.

We characterized the porosity of the $\mathrm{ZnO} /$ carbon monolith and the $\mathrm{ZnO}$ samples. Figure $6 \mathrm{a}$ presents the isotherms of the nitrogen adsorption-desorption of the samples. The isotherm of the $\mathrm{ZnO}$ /carbon monolith suggested that the material was mainly meso-porous $(2 \mathrm{~nm} \leq$ pore size $\leq 50 \mathrm{~nm})$. The stiff rise of the isotherm observed at the higher pressure also indicated the presence of micropores (pore size $<2 \mathrm{~nm}$ ). This was further confirmed in 
the pore size distribution of the $\mathrm{ZnO} /$ carbon monolith (Figure $6 \mathrm{~b}$ ), where the majority of pore diameters ranged from $1 \AA$ to $10 \mathrm{~nm}$. The presence of macropores (pore size $>50 \mathrm{~nm}$ ) up to $1 \mu \mathrm{m}$ pore diameter was also observed in the pore size distribution. The $\mathrm{ZnO} /$ carbon monolith featured a bet surface of $28 \mathrm{~m}^{2} / \mathrm{g}$, with a total pore volume of $0.001 \mathrm{cc} / \mathrm{g}$. In contrast to the $\mathrm{ZnO} /$ carbon monolith, the $\mathrm{ZnO}$ sample was mostly micropores, as indicated by the isotherm (Figure 6a) and the pore size distribution (Figure 6b). Even though the pore size ranged up to $300 \mathrm{~nm}$, the pore size of the maximum occurrences was $1.3 \mathrm{~nm}$. The bet surface area and total pore volume of the $\mathrm{ZnO}$ sample were $78.1 \mathrm{~m}^{2} / \mathrm{g}$ and $0.005 \mathrm{cc} / \mathrm{g}$, respectively.
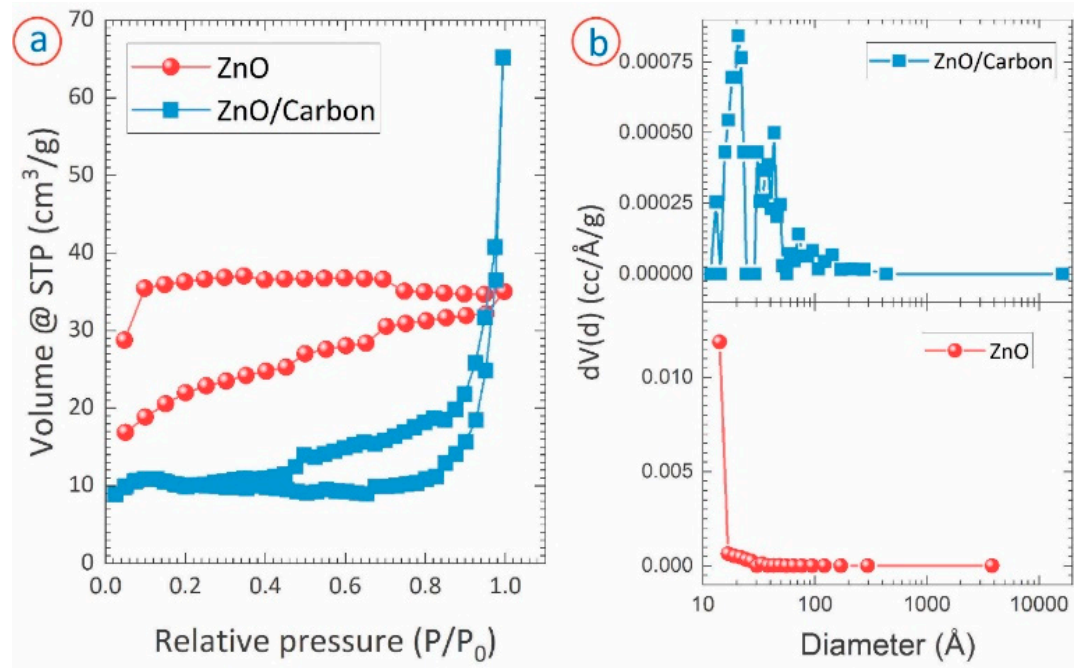

Figure 6. (a) Nitrogen adsorption-desorption isotherm and (b) pore size distribution of $\mathrm{ZnO} /$ carbon monolith obtained from the carbonization of $\mathrm{ZnCl}_{2} / \mathrm{RF}$ and $\mathrm{ZnO}$ nanostructures obtained from the oxidation of $\mathrm{ZnO} /$ carbon monolith.

\section{Discussion}

The carbonization of RF gel is studied several times previously for the preparation of porous carbon monolith [54-58]. During carbonization, RF gel goes through a thermochemical cleavage process, which results in the loss of volatile gases and leaves a carbonrich porous material. With increasing temperature, remaining heteroatoms, including oxygen and hydrogen leaves the carbon matrix. In our work, a similar phenomenon also occurred for the precursor monoliths, both $\mathrm{RF}$ and $\mathrm{ZnCl}_{2} / \mathrm{RF}$. For the $\mathrm{ZnCl}_{2} / \mathrm{RF}$ monolith, the RF-derived carbon further reduced the $\mathrm{ZnCl}_{2}$ counterpart to metallic zinc ( $\mathrm{Zn}$ ) in a carbothermal reduction mechanism. However, the XRD diffractogram of the carbonized $\mathrm{ZnCl}_{2} / \mathrm{RF}$ (Figure 2) also indicated the formation of $\mathrm{ZnO}$ during the carbonization process. Our hypothesis behind such formation of $\mathrm{ZnO}$ is that the carbothermal reduced $\mathrm{Zn}$ might have reacted to the oxygen-rich volatile by-products generated during the thermochemical cleaving of the RF network to form $\mathrm{ZnO}$ nucleation sites. The $\mathrm{ZnO}$ nucleation sites further might have initiated lateral crystal growth engulfing local $\mathrm{Zn}$ atoms and surrounding oxygen-rich molecules, resulting in larger crystallites, as shown in Figure 4d. The dominant peak of the (101) crystal plane in the XRD diffractogram further supported the fact of lateral crystal growth of $\mathrm{ZnO}$. The localized oxidation of $\mathrm{Zn}$ might have also induced localized oxidation of the carbon counterpart, leading to the formation of volatile $\mathrm{CO}$ and $\mathrm{CO}_{2}$ gases. The escape of these volatile gases further contributed to the formation of the micro- and mesopores within the material, as suggested by the gas adsorption results of $\mathrm{ZnO} /$ carbon monolith. Furthermore, the volatile $\mathrm{CO}$ and $\mathrm{CO}_{2}$ might also have contributed to the $\mathrm{ZnO}$ nucleation and growth by locally interacting with the metallic $\mathrm{Zn}$.

The $\mathrm{ZnO}$ obtained from the oxidation of $\mathrm{ZnO} /$ carbon monolith appears green, which is unusual compared to the typical white color of $\mathrm{ZnO}$ nanomaterials. The coloring can be an important aspect in some applications, e.g., UV sensor. Moreover, in this case, coloring 
indicates a high density of defects or charged carriers, which will influence the properties and performances of sensors, solar cells, etc. applications. Schulz et al. reported that the color of $\mathrm{ZnO}$ crystal varies depending on the concentration of oxygen vacancies within the material [59]. Two phenomena occurred during the oxidation of the $\mathrm{ZnO} /$ carbon monolith: the oxidation of unreacted $\mathrm{Zn}$ to $\mathrm{ZnO}$ and the oxidation of the carbon counterpart to form volatile $\mathrm{CO}$ and $\mathrm{CO}_{2}$ gases. The vapor pressure of oxygen and the volatile components during the process might have caused the variation in the concentration of the oxygen vacancies, resulting in the green appearance of the obtained $\mathrm{ZnO}$. The escape of the volatile gases from the quite homogenous monolith of $\mathrm{ZnO} /$ carbon resulted in the formation of the micro- and mesopores, shown in Figure 4e and evidenced by the gas adsorption presented in Figure 6. The $\mathrm{ZnO}$ obtained after the oxidation mostly featured nanorod-like morphology (Figure 4f). The formation of the nanorods might be triggered by the already formed $\mathrm{ZnO}$ crystallites in the $\mathrm{ZnO} /$ carbon monolith. During the oxidation, the oxidation and growth of the $\mathrm{ZnO}$ crystallite occurred in the [1]-direction, which is perpendicular to the hexagonal facet and features the lowest energy for the crystal growth [60]. The preferential growth in the [1]-direction led to the formation of the nanorod shapes. Such direction growth was also supported by a strong (002) peak observed in the XRD diffractogram (Figure 4). Several agglomerated $\mathrm{ZnO}$ structures were also observed in the oxidized sample, which might have resulted from the $\mathrm{Zn} / \mathrm{ZnO}$ embedding within the carbon matrix and the formation during oxidation of the carbon counterpart. Adjacent $\mathrm{Zn} / \mathrm{ZnO}$ particles were oxidized to $\mathrm{ZnO}$ and formed the interconnected network of $\mathrm{ZnO}$, which also contributed to the formation of meso- and macropores. It should be noted that the resulting $\mathrm{ZnO}$ featured a very high surface area. Typically, $\mathrm{ZnO}$ nanostructures feature a surface area ranging from $3 \mathrm{~m}^{2} / \mathrm{g}$ to $50 \mathrm{~m}^{2} / \mathrm{g}$ [61-65]. The surface area $\left(78.1 \mathrm{~m}^{2} / \mathrm{g}\right)$ reported here, to the best of the authors' knowledge, is the highest for $\mathrm{ZnO}$ nanostructures reported to date (see Table 1).

Table 1. Summary of surface area of $\mathrm{ZnO}$ obtained reported in the literature.

\begin{tabular}{|c|c|c|c|c|}
\hline Synthesis Method & Surface Area $\left(\mathrm{m}^{2} / \mathrm{g}\right)$ & Average Pore Size (nm) & Method Used for Surface Area & Reference \\
\hline Precipitating method & 25.36 & 16.0 & $\begin{array}{l}\text { BET nitrogen } \\
\text { adsorption-desorption }\end{array}$ & {$[61]$} \\
\hline Template method & 24 & 17.4 & $\begin{array}{l}\text { BET nitrogen } \\
\text { adsorption-desorption }\end{array}$ & {$[62]$} \\
\hline Combustion method & $8-22$ & - & $\begin{array}{l}\text { BET nitrogen } \\
\text { adsorption-desorption }\end{array}$ & [63] \\
\hline Hydrothermal method & 10.5 & 18.6 & $\begin{array}{l}\text { BET nitrogen } \\
\text { adsorption-desorption }\end{array}$ & {$[64]$} \\
\hline Solvothermal method & 10.5 & 3.5 & $\begin{array}{l}\text { BET nitrogen } \\
\text { adsorption-desorption }\end{array}$ & {$[65]$} \\
\hline $\begin{array}{l}\text { Carbon monolith-based } \\
\text { template method }\end{array}$ & 78.1 & 1.3 & Nitrogen adsorption-desorption & This work \\
\hline
\end{tabular}

\section{Conclusions}

To conclude, we prepared microporous $\mathrm{ZnO}$ nanostructures featuring a high specific surface area. Carbonization of the starting material $\mathrm{ZnCl}_{2} / \mathrm{RF}$ monolith obtained through the sol-gel process resulted in a composite material featuring $\mathrm{Zn}$ and $\mathrm{ZnO}$ embedded within the carbon matrix. Further oxidation of the carbon composite yielded the formation of $\mathrm{ZnO}$ with a mixture of nanorod morphologies and particle agglomeration. The oxidation of the carbon matrix led to the formation of micro- and mesoporous structures of the synthesized $\mathrm{ZnO}$, which yielded a high surface area. Furthermore, synthesis from such carbon-rich material led to the unique green color of the $\mathrm{ZnO}$ material. The morphology and high surface area of the resulting green $\mathrm{ZnO}$ nanostructures will be highly advantageous in the development of high-performance devices for several applications, including sensors, catalysis and photocatalysts, UV-detectors, energy storage devices and solar cells. 


\begin{abstract}
Author Contributions: K.M. and S.S. completed the experiments in the Department of Chemical Engineering, Indian Institute of Technology Kanpur, Kanpur-208016, Uttar Pradesh, India during their Doctorate and Master's studies, respectively, under the supervision of A.S. The manuscript was written through contributions of K.M., M.I., S.S. and A.S. All authors have read and agreed to the published version of the manuscript.
\end{abstract}

Funding: This research received no external funding.

Acknowledgments: The authors want to acknowledge the DST Unit of Excellence on Soft Nanofabrication from the Department of Science and Technology, New Delhi, India for their support. K.M. wants to thank the Energy and Environment S\&T at the Idaho National Laboratory for the support.

Conflicts of Interest: There are no conflicts to declare.

\title{
References
}

1. Islam, M.; Sadaf, A.; Mager, D.; Korvink, J.G. Recent progress on titanium oxide nanostructures for biosensing applications. In Metal Oxides for Biomedical and Biosensor Applications; Elsevier: Amsterdam, The Netherlands, 2022; pp. 437-470.

2. Ali, M.A.; Mondal, K.; Singh, C.; Dhar Malhotra, B.; Sharma, A. Anti-epidermal growth factor receptor conjugated mesoporous zinc oxide nanofibers for breast cancer diagnostics. Nanoscale 2015, 7, 7234-7245. [CrossRef]

3. Septiani, N.L.W.; Saputro, A.G.; Kaneti, Y.V.; Maulana, A.L.; Fathurrahman, F.; Lim, H.; Yuliarto, B.; Nugraha; Dipojono, H.K.; Golberg, D.; et al. Hollow Zinc Oxide Microsphere-Multiwalled Carbon Nanotube Composites for Selective Detection of Sulfur Dioxide. ACS Appl. Nano Mater. 2020, 3, 8982-8996. [CrossRef]

4. Pataniya, P.M.; Late, D.; Sumesh, C.K. Photosensitive $\mathrm{WS}_{2} / \mathrm{ZnO}$ Nano-Heterostructure-Based Electrocatalysts for Hydrogen Evolution Reaction. ACS Appl. Energy Mater. 2021, 4, 755-762. [CrossRef]

5. Wang, Z.; Zhi, M.; Xu, M.; Guo, C.; Man, Z.; Zhang, Z.; Li, Q.; Lv, Y.; Zhao, W.; Yan, J.; et al. Ultrasensitive $\mathrm{NO}_{2}$ gas sensor based on Sb-doped $\mathrm{SnO}_{2}$ covered $\mathrm{ZnO}$ nano-heterojunction. J. Mater. Sci. 2021, 56, 7348-7356. [CrossRef]

6. Kaneti, Y.V.; Moriceau, J.; Liu, M.; Yuan, Y.; Zakaria, Q.; Jiang, X.; Yu, A. Hydrothermal synthesis of ternary $\alpha-\mathrm{Fe} 2 \mathrm{O} 3-\mathrm{ZnO}-\mathrm{Au}$ nanocomposites with high gas-sensing performance. Sens. Actuators B Chem. 2015, 209, 889-897. [CrossRef]

7. Zhou, C.; Wang, Y.; Du, L.; Yao, H.; Wang, J.; Luo, G. Precipitation Preparation of High Surface Area and Porous Nanosized ZnO by Continuous Gas-Based Impinging Streams in Unconfined Space. Ind. Eng. Chem. Res. 2016, 55, 11943-11949. [CrossRef]

8. Singh, P.; Mondal, K.; Sharma, A. Reusable electrospun mesoporous ZnO nanofiber mats for photocatalytic degradation of polycyclic aromatic hydrocarbon dyes in wastewater. J. Colloid Interface Sci. 2013, 394, 208-215. [CrossRef]

9. Srinivasu, P.; Singh, S.P.; Islam, A.; Han, L. Dye-Sensitized Solar Cells Based on High Surface Area Nanocrystalline Zinc Oxide Spheres. Adv. Optoelectron. 2011, 2011, 194508. [CrossRef]

10. Mondal, K.; Sharma, A. Recent advances in the synthesis and application of photocatalytic metal-metal oxide core-shell nanoparticles for environmental remediation and their recycling process. RSC Adv. 2016, 6, 83589-83612. [CrossRef]

11. Mondal, K.; Ali, M.A.; Agrawal, V.V.; Malhotra, B.D.; Sharma, A. Highly Sensitive Biofunctionalized Mesoporous Electrospun TiO 2 Nanofiber Based Interface for Biosensing. ACS Appl. Mater. Interfaces 2014, 6, 2516-2527. [CrossRef]

12. Mondal, K.; Sharma, A. Recent advances in electrospun metal-oxide nanofiber based interfaces for electrochemical biosensing. RSC Adv. 2016, 6, 94595-94616. [CrossRef]

13. Ali, M.A.; Mondal, K.; Jiao, Y.; Oren, S.; Xu, Z.; Sharma, A.; Dong, L. Microfluidic Immuno-Biochip for Detection of Breast Cancer Biomarkers Using Hierarchical Composite of Porous Graphene and Titanium Dioxide Nanofibers. ACS Appl. Mater. Interfaces 2016, 8, 20570-20582. [CrossRef] [PubMed]

14. Wei, J.-S.; Zhu, Z.-Y.; Zhao, X.; Song, T.-B.; Huang, J.-H.; Zhang, Y.-X.; Liu, X.; Chen, L.; Niu, X.-Q.; Wang, Y.-G.; et al. Selfassembled $\mathrm{ZnO}$-carbon dots anode materials for high performance nickel-zinc alkaline batteries. Chem. Eng. J. 2021, $425,130660$. [CrossRef]

15. Ma, Y.; Wang, Z.; Xu, X.; Wang, J. Review on porous nanomaterials for adsorption and photocatalytic conversion of $\mathrm{CO}_{2}$. Chin. J. Catal. 2017, 38, 1956-1969. [CrossRef]

16. Bhanja, P.; Bhaumik, A. Porous nanomaterials as green catalyst for the conversion of biomass to bioenergy. Fuel 2016, $185,432-441$. [CrossRef]

17. Bhanja, P.; Modak, A.; Bhaumik, A. Supported Porous Nanomaterials as Efficient Heterogeneous Catalysts for $\mathrm{CO}_{2}$ Fixation Reactions. Chem. A Eur. J. 2018, 24, 7278-7297. [CrossRef]

18. Verma, P.; Kondo, Y.; Kuwahara, Y.; Kamegawa, T.; Mori, K.; Raja, R.; Yamashita, H. Design and application of photocatalysts using porous materials. Catal. Rev. 2021, 63, 165-233. [CrossRef]

19. Rabiee, N.; Fatahi, Y.; Asadnia, M.; Daneshgar, H.; Kiani, M.; Ghadiri, A.M.; Atarod, M.; Mashhadzadeh, A.H.; Akhavan, O.; Bagherzadeh, M.; et al. Green porous benzamide-like nanomembranes for hazardous cations detection, separation, and concentration adjustment. J. Hazard. Mater. 2022, 423, 127130. [CrossRef]

20. Bharath, G.; Alhseinat, E.; Ponpandian, N.; Khan, M.A.; Siddiqui, M.R.; Ahmed, F.; Alsharaeh, E.H. Development of adsorption and electrosorption techniques for removal of organic and inorganic pollutants from wastewater using novel magnetite/porous graphene-based nanocomposites. Sep. Purif. Technol. 2017, 188, 206-218. [CrossRef] 
21. Wang, C.; Kaneti, Y.V.; Bando, Y.; Lin, J.; Liu, C.; Li, J.; Yamauchi, Y. Metal-organic framework-derived one-dimensional porous or hollow carbon-based nanofibers for energy storage and conversion. Mater. Horizons 2018, 5, 394-407. [CrossRef]

22. Zhou, X.; Cheng, X.; Zhu, Y.; Elzatahry, A.A.; Alghamdi, A.; Deng, Y.; Zhao, D. Ordered porous metal oxide semiconductors for gas sensing. Chin. Chem. Lett. 2018, 29, 405-416. [CrossRef]

23. Sharma, S.; Sahu, B.K.; Cao, L.; Bindra, P.; Kaur, K.; Chandel, M.; Koratkar, N.; Huang, Q.; Shanmugam, V. Porous nanomaterials: Main vein of agricultural nanotechnology. Prog. Mater. Sci. 2021, 121, 100812. [CrossRef]

24. Mamleyev, E.R.; Weidler, P.G.; Nefedov, A.; Szabó, D.V.; Islam, M.; Mager, D.; Korvink, J.G. Nano- and Microstructured Copper/Copper Oxide Composites on Laser-Induced Carbon for Enzyme-Free Glucose Sensors. ACS Appl. Nano Mater. 2021, 4, 13747-13760. [CrossRef]

25. Alizadeh, A.; Jin, X.; Wang, M. Pore-scale Study of Ion Transport Mechanisms in Inhomogeneously Charged Nanoporous Rocks: Impacts of Interface Properties on Macroscopic Transport. J. Geophys. Res. Solid Earth 2019, 124, 5387-5407. [CrossRef]

26. Allaire, G.; Brizzi, R.; Dufrêche, J.-F.; Mikelić, A.; Piatnitski, A. Ion transport in porous media: Derivation of the macroscopic equations using upscaling and properties of the effective coefficients. Comput. Geosci. 2013, 17, 479-495. [CrossRef]

27. Ikonen, T.; Nissinen, T.; Pohjalainen, E.; Sorsa, O.; Kallio, T.; Lehto, V.-P. Electrochemically anodized porous silicon: Towards simple and affordable anode material for Li-ion batteries. Sci. Rep. 2017, 7, 7880. [CrossRef] [PubMed]

28. Parmigiani, A.; Huber, C.; Bachmann, O.; Chopard, B. Pore-scale mass and reactant transport in multiphase porous media flows. J. Fluid Mech. 2011, 686, 40-76. [CrossRef]

29. Nissan, A.; Alcolombri, U.; de Schaetzen, F.; Berkowitz, B.; Jimenez-Martinez, J. Reactive Transport with Fluid-Solid Interactions in Dual-Porosity Media. ACS ES T Water 2021, 1, 259-268. [CrossRef]

30. Kubo, S.; Demir-Cakan, R.; Zhao, L.; White, R.J.; Titirici, M.-M. Porous Carbohydrate-Based Materials via Hard Templating ChemSusChem 2010, 3, 188-194. [CrossRef]

31. Zhang, L.; Jin, L.; Liu, B.; He, J. Templated Growth of Crystalline Mesoporous Materials: From Soft/Hard Templates to Colloidal Templates. Front. Chem. 2019, 7, 22. [CrossRef]

32. Yamagishi, H.; Tsunoda, M.; Iwai, K.; Hengphasatporn, K.; Shigeta, Y.; Sato, H.; Yamamoto, Y. Solvophobicity-directed assembly of microporous molecular crystals. Commun. Chem. 2021, 4, 122. [CrossRef]

33. Decker, G.E.; Lorzing, G.R.; Deegan, M.M.; Bloch, E.D. MOF-mimetic molecules: Carboxylate-based supramolecular complexes as molecular metal-organic framework analogues. J. Mater. Chem. A 2020, 8, 4217-4229. [CrossRef]

34. Wu, L.; Li, Y.; Fu, Z.; Su, B.-L. Hierarchically structured porous materials: Synthesis strategies and applications in energy storage. Natl. Sci. Rev. 2020, 7, 1667-1701. [CrossRef]

35. Ha, J.-H.; Oh, E.; Song, I.-H. The effect of sacrificial templates on the pore characteristics of sintered diatomite membranes. J. Ceram. Soc. Jpn. 2013, 121, 940-945. [CrossRef]

36. Wang, H.; Sung, I.; Li, X.; Kim, D. Fabrication of Porous SiC Ceramics with Special Morphologies by Sacrificing Template Method. J. Porous Mater. 2004, 11, 265-271. [CrossRef]

37. Zhou, Z.; Nonnenmann, S.S. Progress in Nanoporous Templates: Beyond Anodic Aluminum Oxide and Towards Functional Complex Materials. Materials 2019, 12, 2535. [CrossRef]

38. Sharma, A.; Katiyar, S.; Mondal, K. Hierarchical Porous Monoliths and Methods for Their Preparation and Use. U.S. Patent 9,908,102, 6 March 2015.

39. Katiyar, S.; Mondal, K.; Sharma, A. One-step sol-gel synthesis of hierarchically porous, flow-through carbon/silica monoliths. RSC Adv. 2016, 6, 12298-12310. [CrossRef]

40. Lu, A.-H.; Schüth, F. Nanocasting: A Versatile Strategy for Creating Nanostructured Porous Materials. Adv. Mater. 2006, 18, 1793-1805. [CrossRef]

41. Gilmore, J.; Islam, M.; Duncan, J.; Natu, R.; Martinez-Duarte, R. Assessing the importance of the root mean square (RMS) value of different waveforms to determine the strength of a dielectrophoresis trapping force. Electrophoresis 2017, 38, 2561-2564. [CrossRef]

42. Islam, M.; Lantada, A.D.; Gómez, M.R.; Mager, D.; Korvink, J.G. Microarchitectured Carbon Structures as Innovative TissueEngineering Scaffolds. Adv. Eng. Mater. 2020, 22, 2000083. [CrossRef]

43. Islam, M.; Sadaf, A.; Gómez, M.R.; Mager, D.; Korvink, J.G.; Lantada, A.D. Carbon fiber/microlattice 3D hybrid architecture as multi-scale scaffold for tissue engineering. Mater. Sci. Eng. C 2021, 126, 112140. [CrossRef]

44. Sharma, S. Glassy Carbon: A Promising Material for Micro- and Nanomanufacturing. Materials 2018, 11, 1857. [CrossRef] [PubMed]

45. Wang, C.; Madou, M. From MEMS to NEMS with carbon. Biosens. Bioelectron. 2005, 20, 2181-2187. [CrossRef]

46. Singh, S.; Mondal, K.; Sharma, A. ZnO Nanoparticle Fortified Highly Permeable Carbon/Silica Monoliths as a Flow-Through Media. Langmuir 2017, 33, 7692-7700. [CrossRef] [PubMed]

47. Guan, Z.; Guan, Z.; Li, Z.; Liu, J.; Yu, K. Characterization and Preparation of Nano-porous Carbon Derived from Hemp Stems as Anode for Lithium-Ion Batteries. Nanoscale Res. Lett. 2019, 14, 338. [CrossRef]

48. Islam, M.; Weidler, P.G.; Heissler, S.; Mager, D.; Korvink, J.G. Facile template-free synthesis of multifunctional 3D cellular carbon from edible rice paper. RSC Adv. 2020, 10, 16616-16628. [CrossRef]

49. Kakunuri, M.; Vennamalla, S.; Sharma, C.S. Synthesis of carbon xerogel nanoparticles by inverse emulsion polymerization of resorcinol-formaldehyde and their use as anode materials for lithium-ion battery. RSC Adv. 2015, 5, 4747-4753. [CrossRef] 
50. Mitra, J.; Jain, S.; Sharma, A.; Basu, B. Patterned growth and differentiation of neural cells on polymer derived carbon substrates with micro/nano structures in vitro. Carbon N. Y. 2013, 65, 140-155. [CrossRef]

51. Wahab, R.; Ansari, S.G.; Kim, Y.S.; Seo, H.K.; Kim, G.S.; Khang, G.; Shin, H.-S. Low temperature solution synthesis and characterization of ZnO nano-flowers. Mater. Res. Bull. 2007, 42, 1640-1648. [CrossRef]

52. Marie, M.; Mandal, S.; Manasreh, O. An Electrochemical Glucose Sensor Based on Zinc Oxide Nanorods. Sensors 2015, 15, 18714-18723. [CrossRef]

53. Hadžić, B.; Romčević, N.; Sibera, D.; Narkiewicz, U.; Kuryliszyn-Kudelska, I.; Dobrowolski, W.; Romčević, M. Laser power influence on Raman spectra of $\mathrm{ZnO}(\mathrm{Co})$ nanoparticles. J. Phys. Chem. Solids 2016, 91, 80-85. [CrossRef]

54. Roberts, A.D.; Li, X.; Zhang, H. Porous carbon spheres and monoliths: Morphology control, pore size tuning and their applications as Li-ion battery anode materials. Chem. Soc. Rev. 2014, 43, 4341-4356. [CrossRef] [PubMed]

55. Hu, L.; He, R.; Lei, H.; Fang, D. Carbon Aerogel for Insulation Applications: A Review. Int. J. Thermophys. 2019, 40, 39. [CrossRef]

56. Al-Muhtaseb, S.A.; Ritter, J.A. Preparation and Properties of Resorcinol-Formaldehyde Organic and Carbon Gels. Adv. Mater. 2003, 15, 101-114. [CrossRef]

57. Horikawa, T.; Hayashi, J.; Muroyama, K. Controllability of pore characteristics of resorcinol-formaldehyde carbon aerogel. Carbon N. Y. 2004, 42, 1625-1633. [CrossRef]

58. Siyasukh, A.; Maneeprom, P.; Larpkiattaworn, S.; Tonanon, N.; Tanthapanichakoon, W.; Tamon, H.; Charinpanitkul, T. Preparation of a carbon monolith with hierarchical porous structure by ultrasonic irradiation followed by carbonization, physical and chemical activation. Carbon N. Y. 2008, 46, 1309-1315. [CrossRef]

59. Schulz, D.; Ganschow, S.; Klimm, D.; Struve, K. Inductively heated Bridgman method for the growth of zinc oxide single crystals. J. Cryst. Growth 2008, 310, 1832-1835. [CrossRef]

60. Kato, H.; Sano, M.; Miyamoto, K.; Yao, T. Homoepitaxial Growth of High-Quality Zn-Polar ZnO Films by Plasma-Assisted Molecular Beam Epitaxy. Jpn. J. Appl. Phys. 2003, 42, L1002-L1005. [CrossRef]

61. Ismail, M.A.; Taha, K.K.; Modwi, A.; Khezami, L. ZnO nanoparticles: Surface and X-ray profile analysis. J. Ovonic Res. 2018, 14, 381-393.

62. Polarz, S.; Orlov, A.V.; Schüth, F.; Lu, A.-H. Preparation of High-Surface-Area Zinc Oxide with Ordered Porosity, Different Pore Sizes, and Nanocrystalline Walls. Chem. A Eur. J. 2007, 13, 592-597. [CrossRef]

63. Sulciute, A.; Nishimura, K.; Gilshtein, E.; Cesano, F.; Viscardi, G.; Nasibulin, A.G.; Ohno, Y.; Rackauskas, S. ZnO Nanostructures Application in Electrochemistry: Influence of Morphology. J. Phys. Chem. C 2021, 125, 1472-1482. [CrossRef]

64. Liang, Y.; Guo, N.; Li, L.; Li, R.; Ji, G.; Gan, S. Preparation of porous 3D Ce-doped ZnO microflowers with enhanced photocatalytic performance. RSC Adv. 2015, 5, 59887-59894. [CrossRef]

65. Ramakrishnan, V.; Nair, K.G.; Dhakshinamoorthy, J.; Ravi, K.R.; Pullithadathil, B. Porous, n-p type ultra-long, $\mathrm{ZnO@Bi}_{2} \mathrm{O}_{3}$ heterojunction nanorods-based $\mathrm{NO}_{2}$ gas sensor: New insights towards charge transport characteristics. Phys. Chem. Chem. Phys. 2020, 22, 7524-7536. [CrossRef] [PubMed] 